\title{
1 Genomic and Genetic Aspects of Autism Spectrum Disorder
}

2

3 Xiaoxi Liu ${ }^{1}$ and Toru Takumi ${ }^{1,2}$

$4 \quad{ }^{1}$ RIKEN Brain Science Institute, Wako, Saitama 351-0198, Japan

$5 \quad{ }^{2} \mathrm{JST}, \mathrm{CREST}$

6

7 Toru Takumi, M.D., Ph.D.

8 RIKEN Brain Science Institute

9 2-1 Hirosawa, Wako

10 Saitama 351-0198, Japan

11 TEL: +81-48-467-5906

12 FAX: +81-48-467-6079

13 E-mail: toru.takumi@ riken.jp

14 


\section{Abstract}

2 Autism spectrum disorder (ASD) is a neurodevelopmental disorder with a strong genetic

3 component. The past decade has witnessed tremendous progress in the genetic studies of

4 ASD. In this article, we review the accumulating literatures on the monogenic forms of ASD

5 and chromosomal abnormalities associated with ASD, the genome-wide linkage and

6 association studies, the copy number variation $(\mathrm{CNV})$ and the next generation sequencing

7 (NGS) studies. With more than hundreds of mutations being implicated, the convergent

8 biological pathways are emerging and the genetic landscape of ASD becomes clearer. The

9 genetic studies provide a solid basis for future translational study for better diagnoses,

10 intervention and treatment of ASD.

11 (105 words)

12

13 Keywords: autism, autism spectrum disorder, ASD, genetics, CNV

14

15 


\section{Introduction}

2 Autism spectrum disorder (ASD) refers to a wide range of neurodevelopmental conditions

3 characterized by social communication and interaction deficits, stereotyped and repetitive

4 behaviors. According to estimates from U.S. Centers for Disease Control and Prevention

5 (CDC) [1], ASD affects 1 in every 68 children and is considered to be one of the most 6 prevalent childhood disorders.

ASDs are diagnosed solely based on behavioral observation. The diagnostic criteria

8 for ASD have been revised periodically with the reflection of the advances in research and

9 practice. In the previous version of Diagnostic and Statistical Manual of Mental Disorders, 10 fourth edition (DSM-IV) [2], ASD was conceptualized as a manifestation of triad symptoms: 11 impairment in social interaction, impairment in social communication, restricted and 12 repetitive behavior pattern, and included three specific subgroups: Autism, Asperger 13 syndrome, and Pervasive developmental disorder not otherwise specified (PDD-NOS). In the 14 newest version of DSM-5 released in 2013 [3], these subgroups were merged into a single 15 umbrella term as "autism spectrum disorders", and the triad of impairments has been folded 16 into two, with social communication and social interaction combined as a single diagnostic 17 category. In addition to main symptoms, approximately $31 \%$ ASD individuals also present intellectual disability (ID) [1] and 20-25\% have seizures [4]. Other common comorbidities in ASD include anxiety disorders [5], sleep disorders [6], gastrointestinal (GI) disorders [7] and 20 abnormal responses to sensory stimuli [8]. The core symptoms of ASD usually appear before 213 years old and the prevalence of ASD is strongly male-biased with the average male to 22 female ratio around 5:1[1].

ASD has a strong genetic basis. In the twin studies, the concordance rate of broad

24 ASD phenotype in monozygotic twins is $70-90 \%$, but $0-30 \%$ in dizygotic twins $[9,10]$.

25 Family studies indicate that the prevalence of ASD is about 25 times higher in siblings of the 
1 affected individuals than in the general population [11]. Despite being highly heritable, ASD

2 is genetically complex and the underlying genetic architecture is still not well understood.

3 Currently there are two theories to explain the genetic architecture of common complex

4 diseases including ASD [12]. The first is the common variant - common disease (CVCD)

5 hypothesis, which suggests that the genetic risk factor of a complex disorder like ASD, is

6 attributed to many high-frequency (minor allele frequency $>1 \%$ ) genetic variants, each

7 conferring a modest risk (odds ratio < 1.5). These common risk variants collectively

8 contribute to the disease. The second one is the rare variant - common disease (RVCD)

9 hypothesis, suggesting that genetic risk can be mainly explained by rare mutations carrying 10 significant risk. Thus, ASD can be regarded as a collection of many forms of a rare 11 monogenic disorder, each with a different etiology. The RVCD hypothesis is favored by current studies, while the CVCD model cannot be rejected.

In this review, we provide an overview of the ASD genetics by the methodology type,

14 in a chronological order and highlight some key findings. Finally we summarized the 15 convergent pathway and provide our perspective on the issues that should be addressed in the 16 future study.

\section{Monogenic forms of ASD and chromosomal abnormalities}

The identification of the monogenic causes of ASD and the cytogenetic abnormalities provided the initial insight into the genetic components of ASD [13]. Following theses clues, a wide range of studies was conducted and greatly increased the understanding of both genetic and biological mechanisms of ASD.

About $10 \%$ of ASD patients have co-occurring single gene disorders including fragile

$24 \mathrm{X}$ syndrome (FXS), tuberous sclerosis (TSC), Rett syndrome, PTEN hamartoma tumor 25 syndrome (PHTS) and others. FXS is caused by expansions of the trinucleotide CGG repeat 
1 in the FMR1 gene, an RNA-binding gene that plays a pivotal role in synaptic plasticity by

2 regulating the mRNA transport and translation in the brain [14]. The loss-of-function

3 mutations of TSC1 and TSC2 genes are responsible for TSC $[15,16]$. Both genes function as

4 inhibitors in the mammalian target of rapamycin pathway (mTOR) - a key pathway that

5 controls the local translation at the synapse. Rett syndrome, which is caused by mutations in

6 methyl-CpG-binding protein 2 (MeCP2), was found in about 1\% ASD individuals [17]. The

$7 \mathrm{MeCP} 2$ protein has multi-functions and is involved in regulation of transcription; both

8 activation and repression in neurons. The phosphatase and tension homolog (PTEN) gene

9 mutations lead to cancer, seizures and ASD with macrocephaly $[18,19]$. PTEN negatively 10 regulates the PI3K/AKT pathway and indirectly repress mTOR pathway. Collectively, these 11 data implicated that the dysfunction of transcription/translation process in neurons and $12 \mathrm{PI} 3 \mathrm{~K} / \mathrm{AKT} / \mathrm{mTOR}$ pathways contribute to the pathophysiology of ASD. Cytogenetic abnormalities are found in $2 \%$ of ASD individuals by using technology

14 like $\mathrm{G}$ banding karyotyping. The chromosomal abnormalities include 5p15, 15q11-q13, $1517 \mathrm{p} 11,22 \mathrm{q} 11.2$ and others [20]. Of which, the 15q11-q13 locus is the most frequent cause 16 leading to ASD, which may account for close to $1 \%$ of ASD cases. Depending on the 17 mutation type and inherent pattern, this locus gives rise to Prader-Willi syndrome (PWS), 18 Angelmann syndrome (AS), and ASD [21]. A mouse model for 15q11-q13 duplication was generated by a chromosome-engineering technique based on Cre-loxP system and the mice 20 carrying paternally inherited duplication display abnormal autistic-like behaviors such as 21 reduced social interactions and stereotypical behavior [22]. The detailed analysis revealed 22 that the abnormalities of serotonin (5-HT) signaling might be involved in the pathogenesis of 23 ASD [23] and 5-HT pathway might be a promising therapeutic target for ASD.

\section{$25 \quad$ Linkage and candidate gene studies}


1 Linkage analysis is a traditional approach to locate the causal or susceptibility gene by

2 examining the chromosomal regions that co-segregated with the trait among affected

3 pedigrees. It is particularly powerful for Mendelian diseases. Linkage studies were

4 successfully applied to identify MECP2 and FMR1 as causal genes for Rett Syndrome and

5 Fragile X syndrome respectively [17,24]. However, linkage analysis bears several limitations:

6 first it has less power for complex disorder of which the inheritance pattern is not clear and

7 the effect of susceptibility gene is weak; second it requires extended or multiplex families -

8 which is not always feasible; third the chromosomal regions detected are usually broad (10

$9 \mathrm{cM}$ or more) and contain many genes, which requires further fine-mapping to narrow down 10 the candidate region.

11 A number of genome-wide linkage studies have been performed since the first study

12 by International Molecular Genetic Study of Autism Consortium (IMGSAC) in 1998

$13[25,26,27]$. However, these studies met with limited success: suggestive linkage signals were

14 found in almost all chromosomes and there is little consistency among the results. The most 15 replicated linkage loci include chromosome $2 \mathrm{q}, 7 \mathrm{q}$ and $17 \mathrm{q}$.

16 In all implicated linkage regions, chromosome $7 \mathrm{q}$ is the most well supported one and

17 has been implicated in multiple genome-wide scans and meta-analyses [28,29]. Several ASD

18 candidate genes including RELN, FOXP2, WNT2 and CADPS2 were located in this region.

19 RELN encodes an extracellular glycoprotein that has critical roles in the neuronal migration

20 of cortical layers and synaptic remodeling. Despite several studies failed to find association

$21[30,31]$, positive association have been found between polymorphisms in the 5' UTR and

22 intron of RELN and ASD [32,33], and meta-analysis support the association [34]. FOXP2 is a

23 gene important for language development and its mutations have been identified in

24 individuals with speech and language impairment [35]. Despite the biological plausibility,

25 there is little genetic evidence supporting the involvement of FOXP2 in autism [36,37]. 
1 WNT2 belongs to the large WNT gene family and is expressed particularly during the

2 development of the central nervous system. CADPS2 encodes a calcium binding protein and

3 the knockout mouse has abnormal behaviors which are similar to human autistic phenotypes

$4[38]$.

5 The candidate gene approach, which is based on known or suspected biological 6 functions of a given gene, has also been widely applied and a number of candidate genes for

7 ASD have been suggested. The identification of NLGN3 and NLGN4 mutations in ASD

8 siblings is the first important evidence which links the synapse to ASD [39]. This study

9 initiated a wave to identify rare mutations in synaptic genes and it also gave rise to a general concept of "synaptopathy" that suggests synaptic plasticity is an important etiology not only for ASD, but also for neuropsychiatry disorders in general such as schizophrenia and

12 Alzheimer disorder [40,41,42]. Other well-established ASD genes include SHANK3 [43], CNTN4[44] , CNTNAP2 [45], NRXN1[46], and OXTR [47,48].

\section{Genome-wide association study (GWAS)}

GWAS is a powerful data driven approach to identify, without prior knowledge, common

17 variants with low penetrance. By utilizing hundreds of thousands of single-nucleotide polymorphism (SNP) markers in the human genome, GWAS permits an unbiased and comprehensive scan for susceptibility genes and have more statistical power than linkage 20 study.

The first GWAS was reported by Wang et al. in 2009 [49]. By examining 780 ASD

22 families in the discovery stage, an independent cohort of 1,204 ASD cases and 6,491 healthy 23 controls in the replication stage, the authors identified 6 SNPs surpass the genome-wide 24 significance level on chromosome 5p14.1 in combined analyses. The top associated SNP 25 (rs4307059, $P=3.4 \times 10^{-8}$ ) was located in a $2.2 \mathrm{Mb}$ intergenic region between $C D H 9$ and 
1 CDH1O - which encode type II classical cell-cell adhesion molecular cadherin-9 and

2 cadeherin-10. Although rs4307059 was not associated with the expression level of either

3 CDH9 or CDH10, a follow-up study found that a functional $3.9 \mathrm{~kb}$ noncoding RNA is

4 actively transcribed from the top association region [50]. This noncoding RNA corresponds

5 to moesin pseudogene $1(M S N P 1)$ and shares $94 \%$ sequence identity with the mRNA of

$6 M S N$, and was termed as MSNP1AS (moesin psedudogene 1, antisense). MSNP1AS

7 significantly decrease the MSN expression level when overexpressed in vitro. Furthermore

8 the expression of MSNP1AS is correlated with the genotype of rs4307059, where the ASD

9 risk allele homozygote carriers have a 22-fold increase of expression compared with non-risk

10 allele carriers, indicating the ASD associated SNPs may confer the risk by altering the protein

11 level of moesin in certain neurodevelopment periods.

An independent GWAS was conducted by Weiss et al. [51]. Despite that a large proportion of the sample in the screening stage overlap with that of the previous GWAS by

14 Wang et al., the association of 5p14.1 was not replicated in this study. A single SNP rs 10513025 in 5p15 was identified associated with ASD with the genome wide significance $\left(P=2.1 \times 10^{-7}\right)$. This SNP lies between Taste Receptor Type 2 Member $1(T A S 2 R 1)$ and semaphorin 5A (SEMA5A). SEMA5A has been implicated in the axonal guidance and is likely to be a susceptibility gene for ASD. The expression of SEMA5A was found significantly lower in the whole blood as well as occipital lobe cortex in autistic patients compared with healthy controls. In addition, this study also detected several suggestive association signals at loci including JARID2 and JMJD2C, which are plausible ASD candidate genes.

Autism Genome Project consortium further reported two GWAS. In the first stage of

24 this study [52], a genome-wide significant association of MACROD2 was detected by 25 including 1,558 ASD families. However an independent replication study using 1,170 ASD 
1 cases and 35,307 controls could not provided any support for this association [53].

2 Furthermore in the second stage, no SNP was found to be associated with ASD at the

3 genome-wide significance level, even after an increase of the sample size to 2,705 ASD trios

4 [54]. In addition, the previously reported association at MACROD2 was not retained with 5 additional samples.

6 Xia et al. reported an ASD GWAS from the Chinese population [55]. Three SNPs

7 were found with genome-wide significance and gene expression analyses suggest TRIM33

8 and NRAS-CSDE1 might be novel candidate genes for ASD. O TRIM33 is an E3 ubiquitin

9 ligase and is functionally intriguing, as ubiquitin pathway has been implicated in ASD,

10 Angelman Syndrome and X-linked mental retardation.

11 In addition, we also performed a GWAS using Japanese and Chinese ASD

12 individuals. Although no SNP achieved genome-wide significance level combined with the

13 replication study, nominal associations were found in or near ASD candidate genes including

14 CNTN4, JARID2 (Liu et al., unpublished data). In the future, meta-analysis combined or 15 mega-analysis that combines multiple datasets is necessary to increase the power and may 16 shed light on the genetic architecture of ASD.

\section{Copy number variation (CNV)}

$19 \mathrm{CNV}$ is loosely defined as duplication or deletion of a section of DNA with a length usually 20 from $1 \mathrm{~kb}$ to $5 \mathrm{Mb}$. CNVs are widespread in the human genome and account for a substantial 21 proportion of genetic variation and accumulating data highly suggested a critical role of CNV 22 in the etiology of neuropsychiatric disorders, including ASD and schizophrenia, and cancer.

$23 \mathrm{CNV}$ studies, to some extent, are inspired by the early cytogenetic studies and could be 24 regarded as the continuation of such studies but with a much higher resolution. Since a 25 typical size of cytogenetically visible regions is around $5 \mathrm{Mb}$ to $10 \mathrm{Mb}$, this low resolution 
1 greatly limits the ability to identify small-size chromosomal abnormalities including micro-

2 duplication or micro-deletion. With the advancement of technologies including array-

3 comparative genomic hybridization $(\mathrm{aCGH})$ and microarrays, the resolution was highly

4 improved and CNV studies became feasible.

5 In an early CNV study using 10K SNP array, the deletion encompassing NRXNI was

6 identified as a risk factor for ASD [25]. In addition to NRXN1, 1q21, 17q12 and 22q11.21

7 were also implicated. Sebat et al. conducted an important study which focused on de novo

8 CNVs by using aCGH [56]. They observed that rare de novo CNVs were present in $10 \%$ of

9 ASD cases from simplex families, $3 \%$ in multiplex families, but only $1 \%$ in the general

10 population. This indicates that de novo CNVs may account for a significant proportion of the

11 risk factors especially for sporadic ASDs. The high de novo CNV rate in ASDs was further confirmed by other studies, which found de novo rates from $5.8 \%$ to $8.4 \%$ in sporadic ASDs $[57,58,59]$. Marshall et al reported another CNV study on 427 ASD families and they found a similar de novo rate (7.1\% and $2.0 \%$ for simplex and multiplex families respectively)[57]. Furthermore they highlighted the recurrent $\mathrm{CNV}$ loci at $16 \mathrm{p} 11.2$ together with postsynaptic density genes (SHANK3-NLGN4-NRXN1), synapse complex genes (DPP6-DPP10-PCDH9) and others. The association of $16 \mathrm{p} 11.2$ was replicated by another study [60] and a metaanalysis estimated that 16p11.2 may account for approximately $0.76 \%$ of ASD cases [61]. The mouse model for 16p11.2 has also been generated [62].

By using case-control design, Hakonarson and colleagues found the neuronal cell-

21 adhesion molecules and ubiquitin pathway were enriched with CNVs in ASD individuals

22 [63]. In a similar approach, Pinto et al found that ASD cases have a 1.19 fold higher global 23 burden of rare, gene-containing CNVs. Several genes including SHANK2, SYNGAP1 and 24 DLGAP2 were only found in de novo CNV from ASD cases, and were suggested as novel 25 ASD candidate genes [64]. Furthermore by examining maternal inherited CNVs, X-linked 
1 deletions at DDX53-PTCHD1 locus was identified to be significantly associated with ASD.

2 Pathway analysis implicated gene sets that involved in (1) cell and neuronal development and

3 function and (2) GTPase/Ras signaling may play a role in the pathogenesis of ASD.

4

5 Simons Simplex Collection (SSC). These families consist of two healthy parents, a single

6 affected individual and at least one normal sibling. By using different genotyping platform,

7 Sanders et al. and Levy et al. both identified about 80 rare de novo CNVs, and two recurrent

8 de novo CNVs at 16p11.2 (both duplication and deletion) and 7q11.23 (only duplication)

9 were strongly associated with ASD [58,59]. It is interesting to note that the deletion of $107 q 11.23$ has been linked to Williams syndrome, implying that the dosage of genes in this 11 regions is important for the social behaviors. The de novo rates observed in the SSC samples are consistent with previous studies (7.9\% in probands and $2.0 \%$ in unaffected siblings) and it has been found that the female probands carry more and larger de novo CNVs than male

\section{$21 \quad$ Next Generation Sequencing (NGS) Studies}

22 The rapid advances of next-generation sequencing technology have led to the discovery of many rare and de novo point mutations in ASD in the past few years. Brian J O'Roak et al.

24 reported the first whole-exome sequencing study on 20 ASD trios in 2011 [66]. A total of 11 25 missense mutations were identified. Four genes including FOXP1, GRIN2B, SCN1A and 
$1 \quad L A M C 3$ were highlighted as potentially causative genes. However no recurrent mutation was

2 found, which was likely due to the small sample size.

In the first half of 2012, four ASD exome studies were published by independent

4 groups. Wigler and colleagues sequenced exomes of 343 ASD families from SSC [67].

5 Despite that the overall de novo mutation rate is not significantly different between affected

6 and unaffected siblings, the gene-disrupting de novo mutations occur two times more

7 frequent in ASD patients. Furthermore, the likely gene disruption mutations are enriched in

8 FMRP-associated gene set, implicating a shared pathogenesis mechanism between Fragile X

9 syndrome and ASD.

Sanders et al. reported the study with another 238 families of SSC [68]. Consistent

with the previous study, they found the number of non-synonymous de novo mutations were significantly higher in ASD probands than in normal siblings. And the rate of de novo mutation is positively correlated with the paternal age. Further based on statistic modeling and simulation, the authors suggested that it is unlikely to observe two independent de novo mutations in the same gene by chance. They found recurrent mutations in three genes: SCN2A, KATNAL2 and CHD8. The first gene has been implicated in epilepsy where the latter two have not been reported to be associated with ASD.

Neale et al. analyzed the exomes of 175 ASD trios [69]. The correlation between de novo mutation rate and paternal age was further confirmed in this study. Three genes were found in ASD probands with two de novo mutations: BRCA2, FAT1 and KCNMA1. By using in silico protein-protein interaction analysis, the authors found significant enrichment of $d e$

22 novo mutations in 5 ASD candidate genes including STXBP1, MEF2C, KIRREL3, RELN and

23 TUBA1A, and the average distance of non-synonymous variants found in ASD individuals

24 was significant smaller than the comparator, indicating a proportion of the de novo events 25 confer the risk of ASD. 
2 reported 20 trios [70]. They found the de novo mutations are strongly paternal in origin, and a

3 highly interconnected $\beta$-catenin/chromatin remodeling protein network was highlighted

4 which containing $39 \%$ of a total of 120 severely damaging de novo mutations.

In a follow up study, targeted sequencing was performed on 44 candidate genes in

62446 ASD probands from the SSC [71]. A total of 27 de novo events were observed in 16

7 genes. Six genes including CHD8, DYRK1A, GRIN2B, PTEN, TBL1XR1 and TBR1 were

8 found with recurrent de novo mutations. The results further strengthen the previous

9 observation and the author concluded that these six recurrent genes might contribute to $1 \%$ of 10 sporadic ASDs.

\section{Convergent ASD pathways}

13 With the accumulated data, several biological networks are emerging as potential key 14 mechanisms for ASD. On the molecular level, these networks include: synaptic gene transcription and translation pathway (FMR1, TSC1, TSC2, PTEN, NF1, CYF1P1); neural cell adhesion molecules (Nerexin and Neuroligin families, CNTN4); ubiquitination pathway (UBE3A, PARK2, TRIM33); scaffolding protein in sypanse (SHANK2 and SHANK3); ion channel proteins (CACNA1A, CACNA1H, SCN1A, SCN2A); neuron transmitter reporter (GRIN2A, GRIN2B, SLC6A3); chromatin remodeling (CHD8, BAF155) and others. On a higher level, these networks seems to convergent to affect the development and functions of neurons by altering the neuron growth, excitation/inhibition (E/I) balance [72] and activity22 dependent signaling [73].

Systems biology approach and network analysis have also been utilized to understand

24 the convergence of ASD risk factors. By using temporal and spatial gene coexpression 25 network analysis, which is based on nine high-confidence ASD genes identified from NGS 
1 studies, a single group of cortical neurons in layer 5/6 during midfetal development was

2 emerged as significant risk factors to ASD [74]. In a similar methodology but based on a

3 larger list of ASD candidate genes, Geschiwnd and colleagues identified two co-expression

4 modules involved in early transcriptional regulation and synaptic development as key

5 components for ASD [75]. The analysis also suggests ASD genes are more likely to influence

6 superficial cortical layers and glutamatergic projection neurons.

Several ASD databases are now available with detailed annotation of genes and CNV associated with ASD. AutismKB is an evidence based, comprehensive knowledge base for

9 known ASD candidate genes and CNV [76]. By using the curated list of high confidence core 10 ASD genes (171 genes) from AutismDB, we performed the Ingenuity Pathways Analysis 11 (IPA) to identify molecular networks connected with ASD. (IPA, QIAGEN Redwood City, www.qiagen.com/ingenuity). The top three networks were shown in Figure 2 to Figure 4 . The

13 first network is associated with behavior, cell-to-cell signaling and interaction, nervous 14 system development and function. Several network hubs were suggested including AMPA receptor, AKT, actin and RAP1. Abnormal actin is likely to underlie the morphological deficit of neurons in some ASD cases. Recent study reported mutations in SHANK3 affect the 17 dendritic spine morphology via an actin-dependent mechanism [77]. RAP1 has not been implicated as ASD candidate gene, but it was demonstrated as the key regulator for activitydependent dendritic spine structural plasticity [78]. In the second top network, GABA receptors, ERK1/2, MECP2 and BDNF were highlighted. BDNF is the central hub in this 21 network, given its prominent role in neuron growth and differentiation, early BDNF 22 hyperactivity has been hypothesized to be linked with ASD and may account for phenotypes 23 such as early brain outgrowth in ASDs [79]. In the third network, AP1, PTEN and 24 RAS/MAPK signaling pathways were implicated. In addition, a highly conserved gene 
$1 Y$ YWHAE, which plays a role in signal transduction and might responsible for Miller-Dieker

2 syndrome [80], may warrant further study in its relation to ASD.

\section{Future Perspective}

5 To date, hundreds of genetic variants have been implicated in ASD. Although it is estimated

6 that only $1 \%$ of the ASD variance could be explained by common variants - a challenge to

7 the CVCD hypothesis. However, this does not mean that the CVCD hypothesis must be

8 rejected, given that the current sample size has limited power to detect common variants with

9 a modest effect. Future studies with a larger sample size are necessary for the detection of 10 common variants associated with ASD. The importance of rare de novo mutations in the 11 etiology of ASD has been greatly appreciated, but de novo mutations may only account a

12 limited proportion of the genetic risk factor especially in the non-idiopathic ASD cases. A recent study has demonstrated that a large proportion of missing heritability in complex diseases can be explained by genetic interactions from multiple loci [81]. We propose the gene-gene interaction may play significant roles in the etiology of ASD.

Furthermore male predominance in ASD should be addressed in the future studies. It

17 is likely that the female are either under diagnosed or female are more resistant to the genetic perturbation. It is possible that the same ASD risk variant may have a high penetrance in male but a modest effect in female.

Finally the phenotypic and genetic heterogeneity of ASD poses a great challenge to 21 the future study. Since the behavioral and physiological manifestations of ASD vary 22 considerably, appropriate subgrouping by endophenotypes might help to elucidate the 23 divergent mechanisms of ASD. In regard to the phenotypic heterogeneity, it is critical to 24 examine the effect of the variant on the molecular and brain circular level. The emergence of 25 the next generation genome-editing tool like TALEN and CRISPR permit a systematic 
1 investigation by creating isogenic mutated cell or animal model [82]. An integrated approach

2 using multiple methodologies from different disciplines including genetics, neuroscience,

3 molecular biology and others is needed to understand the etiology of ASD.

4

5 Acknowledgements

6 We thank Drs. Takeshi Otowa, Mamoru Tochigi, and Tsukasa Sasaki for critical reading and 7 helpful comments on the manuscript. Our work was supported in part by Japan Society of

8 Promotion of Science and Ministry of Education, Culture, Sports, Science, and Technology

9 KAKENHI, Strategic International Coorperative Program and CREST, Japan Science and 10 Technology Agency.

11

12 


\section{References:}

[1] D.D.M.N.S.Y.P. Investigators, Prevalence of autism spectrum disorder among children aged 8 years - autism and developmental disabilities monitoring network, 11 sites, United States, 2010., MMWR Surveill Summ 63 Suppl 2 (2014) 1-21.

[2] A. American Psychiatric Association, A.P. Association, Diagnostic and statistical manual of mental disorders, (1994).

[3] A.P. Association, The Diagnostic and Statistical Manual of Mental Disorders: DSM 5, (2013).

[4] R. Canitano, Epilepsy in autism spectrum disorders, Eur Child Adolescent Psychiatry 16 (2007) 61-66.

[5] S.W. White, D. Oswald, T. Ollendick, L. Scahill, Anxiety in children and adolescents with autism spectrum disorders, Clinical Psychology Rev 29 (2009) 216-229.

[6] A.L. Richdale, K.A. Schreck, Sleep problems in autism spectrum disorders: prevalence, nature, and possible biopsychosocial aetiologies, Sleep Medicine Rev 13 (2009) 403411.

[7] M. Valicenti-Mcdermott, K. McVICAR, I. Rapin, B.K. WERSHIL, H. Cohen, S. Shinnar, Frequency of gastrointestinal symptoms in children with autistic spectrum disorders and association with family history of autoimmune disease, Journal of Developmental Behavioral Pediatrics 27 (2006) S128-S136.

[8] S.J. Rogers, S. Hepburn, E. Wehner, Parent reports of sensory symptoms in toddlers with autism and those with other developmental disorders, Journal of Autism and Developmental Disorders 33 (2003) 631-642.

[9] R.E. Rosenberg, J.K. Law, G. Yenokyan, J. McGready, W.E. Kaufmann, P.A. Law, Characteristics and concordance of autism spectrum disorders among 277 twin pairs, Archives of Pediatrics and Adolescent Medicine 163 (2009) 907-914.

[10] A. Ronald, R. Hoekstra, Progress in Understanding the Causes of Autism Spectrum Disorders and Autistic Traits: Twin Studies from 1977 to the Present Day, Springer New York, New York, NY, 2014, pp. 33-65.

[11] S. Ozonoff, G.S. Young, A. Carter, D. Messinger, N. Yirmiya, L. Zwaigenbaum, S. Bryson, L.J. Carver, J.N. Constantino, K. Dobkins, Recurrence risk for autism spectrum disorders: a Baby Siblings Research Consortium study, Pediatrics 128 (2011) e488-e495.

[12] W. Bodmer, C. Bonilla, Common and rare variants in multifactorial susceptibility to common diseases, Nat Genetics 40 (2008) 695-701.

[13] S.E. Folstein, B. Rosen-Sheidley, Genetics of autism: complex aetiology for a heterogeneous disorder., Nat Rev Genetics 2 (2001) 943-955.

[14] I. Lokody, Epigenetics: Mechanisms underlying fragile X syndrome, Nat Rev Genetics (2014).

[15] M. van Slegtenhorst, R. de Hoogt, C. Hermans, M. Nellist, B. Janssen, S. Verhoef, D. Lindhout, A. van den Ouweland, D. Halley, J. Young, Identification of the tuberous sclerosis gene TSC1 on chromosome 9q34, Science 277 (1997) 805-808.

[16] E.C.T.S. Consortium, Identification and characterization of the tuberous sclerosis gene on chromosome 16., Cell 75 (1993) 1305.

[17] R.E. Amir, I.B. Van den Veyver, M. Wan, C.Q. Tran, U. Francke, H.Y. Zoghbi, Rett syndrome is caused by mutations in X-linked MECP2, encoding methyl-CpG-binding protein 2, Nat Genetics 23 (1999) 185-188.

[18] J. Li, C. Yen, D. Liaw, K. Podsypanina, S. Bose, S.I. Wang, J. Puc, C. Miliaresis, L. Rodgers, R. McCombie, PTEN, a putative protein tyrosine phosphatase gene mutated in human brain, breast, and prostate cancer, Science 275 (1997) 1943-1947. 
[19] R. Endersby, S.J. Baker, PTEN signaling in brain: neuropathology and tumorigenesis, Oncogene 27 (2008) 5416-5430.

[20] J. Vorstman, W.G. Staal, E. Van Daalen, H. Van Engeland, P. Hochstenbach, L. Franke, Identification of novel autism candidate regions through analysis of reported cytogenetic abnormalities associated with autism, Mol Psychiatry 11 (2006) 18-28.

[21] T. Takumi, The neurobiology of mouse models syntenic to human chromosome 15q, Journal of Neurodevelopmental Disorders 3 (2011) 270-281.

[22] J. Nakatani, K. Tamada, F. Hatanaka, S. Ise, H. Ohta, K. Inoue, S. Tomonaga, Y. Watanabe, Y.J. Chung, R. Banerjee, K. Iwamoto, T. Kato, M. Okazawa, K. Yamauchi, K. Tanda, K. Takao, T. Miyakawa, A. Bradley, T. Takumi, Abnormal Behavior in a Chromosome- Engineered Mouse Model for Human 15q11-13 Duplication Seen in Autism, Cell 137 (2009) 1235-1246.

[23] K. Tamada, S. Tomonaga, F. Hatanaka, N. Nakai, K. Takao, T. Miyakawa, J. Nakatani, T. Takumi, Decreased exploratory activity in a mouse model of $15 \mathrm{q}$ duplication syndrome; implications for disturbance of serotonin signaling, PLoS One 5 (2010) e15126.

[24] A.J. Verkerk, M. Pieretti, J.S. Sutcliffe, Y.-H. Fu, D. Kuhl, A. Pizzuti, O. Reiner, S. Richards, M.F. Victoria, F. Zhang, Identification of a gene (FMR-1) containing a CGG repeat coincident with a breakpoint cluster region exhibiting length variation in fragile X syndrome, Cell 65 (1991) 905-914.

[25] A full genome screen for autism with evidence for linkage to a region on chromosome 7q. International Molecular Genetic Study of Autism Consortium, Hum Mol Genet 7 (1998) 571-578.

[26] I.M.G.S.o.A. Consortium, A genomewide screen for autism: strong evidence for linkage to chromosomes 2q, 7q, and 16p, Am J Hum Genet 69 (2001) 570.

[27] P. Szatmari, A.D. Paterson, L. Zwaigenbaum, W. Roberts, J. Brian, X.-Q. Liu, J.B. Vincent, J.L. Skaug, A.P. Thompson, L. Senman, L. Feuk, C. Qian, S.E. Bryson, M.B. Jones, C.R. Marshall, S.W. Scherer, V.J. Vieland, C. Bartlett, L.V. Mangin, R. Goedken, A. Segre, M.A. Pericak-Vance, M.L. Cuccaro, J.R. Gilbert, H.H. Wright, R.K. Abramson, C. Betancur, T. Bourgeron, C. Gillberg, M. Leboyer, J.D. Buxbaum, K.L. Davis, E. Hollander, J.M. Silverman, J. Hallmayer, L. Lotspeich, J.S. Sutcliffe, J.L. Haines, S.E. Folstein, J. Piven, T.H. Wassink, V. Sheffield, D.H. Geschwind, M. Bucan, W.T. Brown, R.M. Cantor, J.N. Constantino, T.C. Gilliam, M. Herbert, C. LaJonchere, D.H. Ledbetter, C. Lese-Martin, J. Miller, S. Nelson, C.A. SamangoSprouse, S. Spence, M. State, R.E. Tanzi, H. Coon, G. Dawson, B. Devlin, A. Estes, P. Flodman, L. Klei, W.M. McMahon, N. Minshew, J. Munson, E. Korvatska, P.M. Rodier, G.D. Schellenberg, M. Smith, M.A. Spence, C. Stodgell, P.G. Tepper, E.M. Wijsman, C.-E. Yu, B. Roge, C. Mantoulan, K. Wittemeyer, A. Poustka, B. Felder, S.M. Klauck, C. Schuster, F. Poustka, S. Bölte, S. Feineis-Matthews, E. Herbrecht, G. Schmötzer, J. Tsiantis, K. Papanikolaou, E. Maestrini, E. Bacchelli, F. Blasi, S. Carone, C. Toma, H. Van Engeland, M. de Jonge, C. Kemner, F. Koop, M. Langemeijer, et al., Mapping autism risk loci using genetic linkage and chromosomal rearrangements, Nat Genetics 39 (2007) 319-328.

[28] J.A. Badner, E.S. Gershon, Regional meta-analysis of published data supports linkage of autism with markers on chromosome 7, Mol Psychiatry 7 (2002) 56-66.

[29] M. Alarcón, R.M. Cantor, J. Liu, T.C. Gilliam, D.H. Geschwind, Evidence for a language quantitative trait locus on chromosome $7 q$ in multiplex autism families, Am J Hum Genet 70 (2002) 60-71.

[30] J. Li, L. Nguyen, C. Gleason, L. Lotspeich, D. Spiker, N. Risch, R.M. Myers, Lack of evidence for an association between WNT2 and RELN polymorphisms and autism, 
American Journal of Medical Genetics Part B: Neuropsychiatric Genetics 126 (2004) 51-57.

[31] H. Li, Y. Li, J. Shao, R. Li, Y. Qin, C. Xie, Z. Zhao, The association analysis of RELN and GRM8 genes with autistic spectrum disorder in Chinese Han population, American Journal of Medical Genetics Part B: Neuropsychiatric Genetics 147 (2008) 194-200.

[32] H. Zhang, X. Liu, C. Zhang, E. Mundo, F. Macciardi, D.R. Grayson, A.R. Guidotti, J.J. Holden, Reelin gene alleles and susceptibility to autism spectrum disorders., Mol Psychiatry 7 (2001) 1012-1017.

[33] D.A. Skaar, Y. Shao, J.L. Haines, J.E. Stenger, J. Jaworski, E.R. Martin, G.R. DeLong, J.H. Moore, J.L. McCauley, J.S. Sutcliffe, Analysis of the RELN gene as a genetic risk factor for autism, Mol Psychiatry 10 (2004) 563-571.

[34] Z. Wang, Y. Hong, L. Zou, R. Zhong, B. Zhu, N. Shen, W. Chen, J. Lou, J. Ke, T. Zhang, W. Wang, X. Miao, Reelin gene variants and risk of autism spectrum disorders: An integrated meta-analysis, American Journal of Medical Genetics 165 (2014) 192-200.

[35] W. Enard, M. Przeworski, S.E. Fisher, C.S. Lai, V. Wiebe, T. Kitano, A.P. Monaco, S. Pääbo, Molecular evolution of FOXP2, a gene involved in speech and language, Nature 418 (2002) 869-872.

[36] D.F. Newbury, E. Bonora, J.A. Lamb, S.E. Fisher, C.S. Lai, G. Baird, L. Jannoun, V. Slonims, C.M. Stott, M.J. Merricks, P.F. Bolton, A.J. Bailey, A.P. Monaco, C. International Molecular Genetic Study of Autism, FOXP2 is not a major susceptibility gene for autism or specific language impairment, Am J Hum Genet 70 (2002) 13181327.

[37] T. Marui, S. Koishi, I. Funatogawa, K. Yamamoto, H. Matsumoto, O. Hashimoto, E. Nanba, C. Kato, M. Ishijima, K. Watanabe, K. Kasai, N. Kato, T. Sasaki, No association of FOXP2 and PTPRZ1 on 7q31 with autism from the Japanese population, Neuroscience Research 53 (2005) 91-94.

[38] T. Sadakata, M. Washida, Y. Iwayama, S. Shoji, Y. Sato, T. Ohkura, R. Katoh-Semba, M. Nakajima, Y. Sekine, M. Tanaka, K. Nakamura, Y. Iwata, K.J. Tsuchiya, N. Mori, S.D. Detera-Wadleigh, H. Ichikawa, S. Itohara, T. Yoshikawa, T. Furuichi, Autisticlike phenotypes in Cadps2-knockout mice and aberrant CADPS2 splicing in autistic patients, Journal of Clinical Investigation 117 (2007) 931-943.

[39] S. Jamain, H. Quach, C. Betancur, M. Råstam, C. Colineaux, I.C. Gillberg, H. Soderstrom, B. Giros, M. Leboyer, C. Gillberg, T. Bourgeron, Paris Autism Research Internationla Sibpair Study Van Maldergem, Mutations of the X-linked genes encoding neuroligins NLGN3 and NLGN4 are associated with autism, Nat Genetics 34 (2003) 27-29.

[40] T. Bourgeron, A synaptic trek to autism, Curr Opin Neurobiol 19 (2009) 231-234.

[41] K.E. Stephan, T. Baldeweg, K.J. Friston, Synaptic plasticity and dysconnection in schizophrenia, Biol Psychiatry 59 (2006) 929-939.

[42] G.M. Shankar, S. Li, T.H. Mehta, A. Garcia-Munoz, N.E. Shepardson, I. Smith, F.M. Brett, M.A. Farrell, M.J. Rowan, C.A. Lemere, C.M. Regan, D.M. Walsh, B.L. Sabatini, D.J. Selkoe, Amyloid-beta protein dimers isolated directly from Alzheimer's brains impair synaptic plasticity and memory, Nat Med 14 (2008) 837-842.

[43] C.M. Durand, C. Betancur, T.M. Boeckers, J. Bockmann, P. Chaste, F. Fauchereau, G. Nygren, M. Råstam, I.C. Gillberg, H. Anckarsäter, Mutations in the gene encoding the synaptic scaffolding protein SHANK3 are associated with autism spectrum disorders, Nat Genetics 39 (2007) 25-27. 
[44] T. Fernandez, T. Morgan, N. Davis, A. Klin, A. Morris, A. Farhi, R.P. Lifton, M.W. State, Disruption of contactin 4 (CNTN4) results in developmental delay and other features of 3p deletion syndrome, Am J Hum Genet 74 (2004) 1286-1293.

[45] D.E. Arking, D.J. Cutler, C.W. Brune, T.M. Teslovich, K. West, M. Ikeda, A. Rea, M. Guy, S. Lin, E.H. Cook, A. Chakravarti, A common genetic variant in the neurexin superfamily member CNTNAP2 increases familial risk of autism, Am J Hum Genet 82 (2008) 160-164.

[46] X. Chen, Y. Shen, F. Zhang, C. Chiang, V. Pillalamarri, I. Blumenthal, M. Talkowski, B.L. Wu, J.F. Gusella, Molecular analysis of a deletion hotspot in the NRXN1 region reveals the involvement of short inverted repeats in deletion CNVs, Am J Hum Genet 92 (2013) 375-386.

[47] S. Wu, M. Jia, Y. Ruan, J. Liu, Y. Guo, M. Shuang, X. Gong, Y. Zhang, X. Yang, D. Zhang, Positive association of the oxytocin receptor gene (OXTR) with autism in the Chinese Han population, Biol Psychiatry 58 (2005) 74-77.

[48] X. Liu, Y. Kawamura, T. Shimada, T. Otowa, S. Koishi, T. Sugiyama, H. Nishida, O. Hashimoto, R. Nakagami, M. Tochigi, T. Umekage, Y. Kano, T. Miyagawa, N. Kato, K. Tokunaga, T. Sasaki, Association of the oxytocin receptor (OXTR) gene polymorphisms with autism spectrum disorder (ASD) in the Japanese population, $\mathbf{J}$ Hum Genet 55 (2010) 137-141.

[49] K. Wang, H. Zhang, D. Ma, M. Bucan, J.T. Glessner, B.S. Abrahams, D. Salyakina, M. Imielinski, J.P. Bradfield, P.M.A. Sleiman, C.E. Kim, C. Hou, E. Frackelton, R. Chiavacci, N. Takahashi, T. Sakurai, E. Rappaport, C.M. Lajonchere, J. Munson, A. Estes, O. Korvatska, J. Piven, L.I. Sonnenblick, A.I. Alvarez Retuerto, E.I. Herman, H. Dong, T. Hutman, M. Sigman, S. Ozonoff, A. Klin, T. Owley, J.A. Sweeney, C.W. Brune, R.M. Cantor, R. Bernier, J.R. Gilbert, M.L. Cuccaro, W.M. McMahon, J. Miller, M.W. State, T.H. Wassink, H. Coon, S.E. Levy, R.T. Schultz, J.I. Nurnberger, J.L. Haines, J.S. Sutcliffe, E.H. Cook, N.J. Minshew, J.D. Buxbaum, G. Dawson, S.F.A. Grant, D.H. Geschwind, M.A. Pericak-Vance, G.D. Schellenberg, H. Hakonarson, Common genetic variants on 5p14.1 associate with autism spectrum disorders, Nature 459 (2009) 528-533.

[50] T. Kerin, A. Ramanathan, K. Rivas, N. Grepo, G.A. Coetzee, D.B. Campbell, A noncoding RNA antisense to moesin at 5p14.1 in autism, Sci Transl Med 4 (2012) $128 \mathrm{ra} 140$.

[51] L.A. Weiss, D.E. Arking, H. Gene Discovery Project of Johns, C. the Autism, M.J. Daly, A. Chakravarti, A genome-wide linkage and association scan reveals novel loci for autism, Nature 461 (2009) 802-808.

[52] R. Anney, L. Klei, D. Pinto, R. Regan, J. Conroy, T.R. Magalhaes, C. Correia, B.S. Abrahams, N. Sykes, A.T. Pagnamenta, J. Almeida, E. Bacchelli, A.J. Bailey, G. Baird, A. Battaglia, T. Berney, N. Bolshakova, S. Bolte, P.F. Bolton, T. Bourgeron, S. Brennan, J. Brian, A.R. Carson, G. Casallo, J. Casey, S.H. Chu, L. Cochrane, C. Corsello, E.L. Crawford, A. Crossett, G. Dawson, M. de Jonge, R. Delorme, I. Drmic, E. Duketis, F. Duque, A. Estes, P. Farrar, B.A. Fernandez, S.E. Folstein, E. Fombonne, C.M. Freitag, J. Gilbert, C. Gillberg, J.T. Glessner, J. Goldberg, J. Green, S.J. Guter, H. Hakonarson, E.A. Heron, M. Hill, R. Holt, J.L. Howe, G. Hughes, V. Hus, R. Igliozzi, C. Kim, S.M. Klauck, A. Kolevzon, O. Korvatska, V. Kustanovich, C.M. Lajonchere, J.A. Lamb, M. Laskawiec, M. Leboyer, A. Le Couteur, B.L. Leventhal, A.C. Lionel, X.Q. Liu, C. Lord, L. Lotspeich, S.C. Lund, E. Maestrini, W. Mahoney, C. Mantoulan, C.R. Marshall, H. McConachie, C.J. McDougle, J. McGrath, W.M. McMahon, N.M. Melhem, A. Merikangas, O. Migita, N.J. Minshew, G.K. Mirza, J. Munson, S.F. Nelson, C. Noakes, A. Noor, G. Nygren, G. Oliveira, K. 
Papanikolaou, J.R. Parr, B. Parrini, T. Paton, A. Pickles, J. Piven, D.J. Posey, A. Poustka, F. Poustka, et al., A genome-wide scan for common alleles affecting risk for autism, Hum Mol Genet 19 (2010) 4072-4082.

[53] S. Curran, P. Bolton, K. Rozsnyai, A. Chiocchetti, S.M. Klauck, E. Duketis, F. Poustka, S. Schlitt, C.M. Freitag, I. Lee, No association between a common single nucleotide polymorphism, rs4141463, in the MACROD2 gene and autism spectrum disorder, American Journal of Medical Genetics Part B: Neuropsychiatric Genetics 156 (2011) 633-639.

[54] R. Anney, L. Klei, D. Pinto, J. Almeida, E. Bacchelli, G. Baird, N. Bolshakova, S. Bolte, P.F. Bolton, T. Bourgeron, S. Brennan, J. Brian, J. Casey, J. Conroy, C. Correia, C. Corsello, E.L. Crawford, M. de Jonge, R. Delorme, E. Duketis, F. Duque, A. Estes, P. Farrar, B.A. Fernandez, S.E. Folstein, E. Fombonne, J. Gilbert, C. Gillberg, J.T. Glessner, A. Green, J. Green, S.J. Guter, E.A. Heron, R. Holt, J.L. Howe, G. Hughes, V. Hus, R. Igliozzi, S. Jacob, G.P. Kenny, C. Kim, A. Kolevzon, V. Kustanovich, C.M. Lajonchere, J.A. Lamb, M. Law-Smith, M. Leboyer, A. Le Couteur, B.L. Leventhal, X.Q. Liu, F. Lombard, C. Lord, L. Lotspeich, S.C. Lund, T.R. Magalhaes, C. Mantoulan, C.J. McDougle, N.M. Melhem, A. Merikangas, N.J. Minshew, G.K. Mirza, J. Munson, C. Noakes, G. Nygren, K. Papanikolaou, A.T. Pagnamenta, B. Parrini, T. Paton, A. Pickles, D.J. Posey, F. Poustka, J. Ragoussis, R. Regan, W. Roberts, K. Roeder, B. Roge, M.L. Rutter, S. Schlitt, N. Shah, V.C. Sheffield, L. Soorya, I. Sousa, V. Stoppioni, N. Sykes, R. Tancredi, A.P. Thompson, S. Thomson, A. Tryfon, J. Tsiantis, H. Van Engeland, J.B. Vincent, F. Volkmar, J.A. Vorstman, S. Wallace, K. Wing, K. Wittemeyer, S. Wood, D. Zurawiecki, L. Zwaigenbaum, A.J. Bailey, et al., Individual common variants exert weak effects on the risk for autism spectrum disorderspi, Hum Mol Genet 21 (2012) 4781-4792.

[55] K. Xia, H. Guo, Z. Hu, G. Xun, L. Zuo, Y. Peng, K. Wang, Y. He, Z. Xiong, L. Sun, Q. Pan, Z. Long, X. Zou, X. Li, W. Li, X. Xu, L. Lu, Y. Liu, Y. Hu, D. Tian, L. Long, J. Ou, Y. Liu, X. Li, L. Zhang, Y. Pan, J. Chen, H. Peng, Q. Liu, X. Luo, W. Su, L. Wu, D. Liang, H. Dai, X. Yan, Y. Feng, B. Tang, J. Li, Z. Miedzybrodzka, J. Xia, Z. Zhang, X. Luo, X. Zhang, D. St Clair, J. Zhao, F. Zhang, Common genetic variants on 1p13.2 associate with risk of autism, Mol Psychiatry (2013).

[56] J. Sebat, B. Lakshmi, D. Malhotra, J. Troge, C. Lese-Martin, T. Walsh, B. Yamrom, S. Yoon, A. Krasnitz, J. Kendall, A. Leotta, D. Pai, R. Zhang, Y.H. Lee, J. Hicks, S.J. Spence, A.T. Lee, K. Puura, T. Lehtimaki, D. Ledbetter, P.K. Gregersen, J. Bregman, J.S. Sutcliffe, V. Jobanputra, W. Chung, D. Warburton, M.C. King, D. Skuse, D.H. Geschwind, T.C. Gilliam, K. Ye, M. Wigler, Strong Association of De Novo Copy Number Mutations with Autism, Science 316 (2007) 445-449.

[57] C.R. Marshall, A. Noor, J.B. Vincent, A.C. Lionel, L. Feuk, J. Skaug, M. Shago, R. Moessner, D. Pinto, Y. Ren, B. Thiruvahindrapduram, A. Fiebig, S. Schreiber, J. Friedman, C.E.J. Ketelaars, Y.J. Vos, C. Ficicioglu, S. Kirkpatrick, R. Nicolson, L. Sloman, A. Summers, C.A. Gibbons, A. Teebi, D. Chitayat, R. Weksberg, A. Thompson, C. Vardy, V. Crosbie, S. Luscombe, R. Baatjes, L. Zwaigenbaum, W. Roberts, B. Fernandez, P. Szatmari, S.W. Scherer, Structural Variation of Chromosomes in Autism Spectrum Disorder, Am J Hum Genet 82 (2008) 477-488.

[58] S.J. Sanders, A.G. Ercan-Sencicek, V. Hus, R. Luo, M.T. Murtha, D. Moreno-De-Luca, S.H. Chu, M.P. Moreau, A.R. Gupta, S.A. Thomson, C.E. Mason, K. Bilguvar, P.B.S. Celestino-Soper, M. Choi, E.L. Crawford, L. Davis, N.R.D. Wright, R.M. Dhodapkar, M. DiCola, N.M. DiLullo, T.V. Fernandez, V. Fielding-Singh, D.O. Fishman, S. Frahm, R. Garagaloyan, G.S. Goh, S. Kammela, L. Klei, J.K. Lowe, S.C. Lund, A.D. McGrew, K.A. Meyer, W.J. Moffat, J.D. Murdoch, B.J. O\&apos;Roak, G.T. Ober, 
R.S. Pottenger, M.J. Raubeson, Y. Song, Q. Wang, B.L. Yaspan, T.W. Yu, I.R. Yurkiewicz, A.L. Beaudet, R.M. Cantor, M. Curland, D.E. Grice, M. Günel, R.P. Lifton, S.M. Mane, D.M. Martin, C.A. Shaw, M. Sheldon, J.A. Tischfield, C.A. Walsh, E.M. Morrow, D.H. Ledbetter, E. Fombonne, C. Lord, C.L. Martin, A.I. Brooks, J.S. Sutcliffe, E.H. Cook Jr, D. Geschwind, K. Roeder, B. Devlin, M.W. State, Multiple Recurrent De Novo CNVs, Including Duplications of the 7q11.23 Williams Syndrome Region, Are Strongly Associated with Autism, Neuron 70 (2011) 863-885.

[59] D. Levy, M. Ronemus, B. Yamrom, Y.-h. Lee, A. Leotta, J. Kendall, S. Marks, B. Lakshmi, D. Pai, K. Ye, A. Buja, A. Krieger, S. Yoon, J. Troge, L. Rodgers, I. Iossifov, M. Wigler, Rare De Novo and Transmitted Copy-Number Variation in Autistic Spectrum Disorders, Neuron 70 (2011) 886-897.

[60] L.A. Weiss, Y. Shen, J.M. Korn, D.E. Arking, D.T. Miller, R. Fossdal, E. Saemundsen, H. Stefansson, M.A.R. Ferreira, T. Green, O.S. Platt, D.M. Ruderfer, C.A. Walsh, D. Altshuler, A. Chakravarti, R.E. Tanzi, K. Stefansson, S.L. Santangelo, J.F. Gusella, P. Sklar, B.-L. Wu, M.J. Daly, A. Consortium, Association between microdeletion and microduplication at 16p11.2 and autism., The New England Journal of Medicine 358 (2008) 667-675.

[61] K.M. Walsh, M.B. Bracken, Copy number variation in the dosage-sensitive 16p11.2 interval accounts for only a small proportion of autism incidence: A systematic review and meta-analysis, Genetics in Medicine 13 (2011) 377-384.

[62] G. Horev, J. Ellegood, J.P. Lerch, Y.E. Son, L. Muthuswamy, H. Vogel, A.M. Krieger, A. Buja, R.M. Henkelman, M. Wigler, A.A. Mills, Dosage-dependent phenotypes in models of 16p11.2 lesions found in autism, Proc Natl Acad Sci U S A 108 (2011) 17076-17081.

[63] J.T. Glessner, K. Wang, G. Cai, O. Korvatska, C.E. Kim, S. Wood, H. Zhang, A. Estes, C.W. Brune, J.P. Bradfield, M. Imielinski, E.C. Frackelton, J. Reichert, E.L. Crawford, J. Munson, P.M.A. Sleiman, R. Chiavacci, K. Annaiah, K. Thomas, C. Hou, W. Glaberson, J. Flory, F. Otieno, M. Garris, L. Soorya, L. Klei, J. Piven, K.J. Meyer, E. Anagnostou, T. Sakurai, R.M. Game, D.S. Rudd, D. Zurawiecki, C.J. McDougle, L.K. Davis, J. Miller, D.J. Posey, S. Michaels, A. Kolevzon, J.M. Silverman, R. Bernier, S.E. Levy, R.T. Schultz, G. Dawson, T. Owley, W.M. McMahon, T.H. Wassink, J.A. Sweeney, J.I. Nurnberger, H. Coon, J.S. Sutcliffe, N.J. Minshew, S.F.A. Grant, M. Bucan, E.H. Cook, J.D. Buxbaum, B. Devlin, G.D. Schellenberg, H. Hakonarson, Autism genome-wide copy number variation reveals ubiquitin and neuronal genes, Nature 459 (2009) 569-573.

[64] D. Pinto, A.T. Pagnamenta, L. Klei, R. Anney, D. Merico, R. Regan, J. Conroy, T.R. Magalhaes, C. Correia, B.S. Abrahams, J. Almeida, E. Bacchelli, G.D. Bader, A.J. Bailey, G. Baird, A. Battaglia, T. Berney, N. Bolshakova, S. Bölte, P.F. Bolton, T. Bourgeron, S. Brennan, J. Brian, S.E. Bryson, A.R. Carson, G. Casallo, J. Casey, B.H.Y. Chung, L. Cochrane, C. Corsello, E.L. Crawford, A. Crossett, C. Cytrynbaum, G. Dawson, M. de Jonge, R. Delorme, I. Drmic, E. Duketis, F. Duque, A. Estes, P. Farrar, B.A. Fernandez, S.E. Folstein, E. Fombonne, C.M. Freitag, J. Gilbert, C. Gillberg, J.T. Glessner, J. Goldberg, A. Green, J. Green, S.J. Guter, H. Hakonarson, E.A. Heron, M. Hill, R. Holt, J.L. Howe, G. Hughes, V. Hus, R. Igliozzi, C. Kim, S.M. Klauck, A. Kolevzon, O. Korvatska, V. Kustanovich, C.M. Lajonchere, J.A. Lamb, M. Laskawiec, M. Leboyer, A. Le Couteur, B.L. Leventhal, A.C. Lionel, X.-Q. Liu, C. Lord, L. Lotspeich, S.C. Lund, E. Maestrini, W. Mahoney, C. Mantoulan, C.R. Marshall, H. McConachie, C.J. McDougle, J. McGrath, W.M. McMahon, A. Merikangas, O. Migita, N.J. Minshew, G.K. Mirza, J. Munson, S.F. Nelson, C. 
Noakes, A. Noor, G. Nygren, G. Oliveira, K. Papanikolaou, J.R. Parr, B. Parrini, T. Paton, A. Pickles, M. Pilorge, et al., Functional impact of global rare copy number variation in autism spectrum disorders., Nature 466 (2010) 368-372.

[65] S.R. Gilman, I. Iossifov, D. Levy, M. Ronemus, M. Wigler, D. Vitkup, Rare De Novo Variants Associated with Autism Implicate a Large Functional Network of Genes Involved in Formation and Function of Synapses, Neuron 70 (2011) 898-907.

[66] B.J. O'Roak, P. Deriziotis, C. Lee, L. Vives, J.J. Schwartz, S. Girirajan, E. Karakoc, A.P. Mackenzie, S.B. Ng, C. Baker, M.J. Rieder, D.A. Nickerson, R. Bernier, S.E. Fisher, J. Shendure, E.E. Eichler, Exome sequencing in sporadic autism spectrum disorders identifies severe de novo mutations, Nat Genet 43 (2011) 585-589.

[67] I. Iossifov, M. Ronemus, D. Levy, Z. Wang, I. Hakker, J. Rosenbaum, B. Yamrom, Y.-h. Lee, G. Narzisi, A. Leotta, J. Kendall, E. Grabowska, B. Ma, S. Marks, L. Rodgers, A. Stepansky, J. Troge, P. Andrews, M. Bekritsky, K. Pradhan, E. Ghiban, M. Kramer, J. Parla, R. Demeter, L.L. Fulton, R.S. Fulton, V.J. Magrini, K. Ye, J.C. Darnell, R.B. Darnell, E.R. Mardis, R.K. Wilson, M.C. Schatz, W.R. McCombie, M. Wigler, De Novo Gene Disruptions in Children on the Autistic Spectrum, Neuron 74 (2012) 285-299.

[68] S.J. Sanders, M.T. Murtha, A.R. Gupta, J.D. Murdoch, M.J. Raubeson, A.J. Willsey, A.G. Ercan-Sencicek, N.M. DiLullo, N.N. Parikshak, J.L. Stein, M.F. Walker, G.T. Ober, N.A. Teran, Y. Song, P. El-Fishawy, R.C. Murtha, M. Choi, J.D. Overton, R.D. Bjornson, N.J. Carriero, K.A. Meyer, K. Bilguvar, S.M. Mane, N. Šestan, R.P. Lifton, M. Günel, K. Roeder, D.H. Geschwind, B. Devlin, M.W. State, De novo mutations revealed by whole-exome sequencing are strongly associated with autism., Nature 485 (2012) 237-241.

[69] B.M. Neale, Y. Kou, L. Liu, A. Ma'ayan, K.E. Samocha, A. Sabo, C.-F. Lin, C. Stevens, L.-S. Wang, V. Makarov, P. Polak, S. Yoon, J. Maguire, E.L. Crawford, N.G. Campbell, E.T. Geller, O. Valladares, C. Schafer, H. Liu, T. Zhao, G. Cai, J. Lihm, R. Dannenfelser, O. Jabado, Z. Peralta, U. Nagaswamy, D. Muzny, J.G. Reid, I. Newsham, Y. Wu, L. Lewis, Y. Han, B.F. Voight, E. Lim, E. Rossin, A. Kirby, J. Flannick, M. Fromer, K. Shakir, T. Fennell, K. Garimella, E. Banks, R. Poplin, S. Gabriel, M. DePristo, J.R. Wimbish, B.E. Boone, S.E. Levy, C. Betancur, S. Sunyaev, E. Boerwinkle, J.D. Buxbaum, E.H. Cook, B. Devlin, R.A. Gibbs, K. Roeder, G.D. Schellenberg, J.S. Sutcliffe, M.J. Daly, Patterns and rates of exonic de novo mutations in autism spectrum disorders., Nature 485 (2012) 242-245.

[70] B.J. O'Roak, L. Vives, S. Girirajan, E. Karakoc, N. Krumm, B.P. Coe, R. Levy, A. Ko, C. Lee, J.D. Smith, E.H. Turner, I.B. Stanaway, B. Vernot, M. Malig, C. Baker, B. Reilly, J.M. Akey, E. Borenstein, M.J. Rieder, D.A. Nickerson, R. Bernier, J. Shendure, E.E. Eichler, Sporadic autism exomes reveal a highly interconnected protein network of de novo mutations, Nature 485 (2012) 246-250.

[71] B.J. O'Roak, L. Vives, W. Fu, J.D. Egertson, I.B. Stanaway, I.G. Phelps, G. Carvill, A. Kumar, C. Lee, K. Ankenman, J. Munson, J.B. Hiatt, E.H. Turner, R. Levy, D.R. O'Day, N. Krumm, B.P. Coe, B.K. Martin, E. Borenstein, D.A. Nickerson, H.C. Mefford, D. Doherty, J.M. Akey, R. Bernier, E.E. Eichler, J. Shendure, Multiplex targeted sequencing identifies recurrently mutated genes in autism spectrum disorders, Science 338 (2012) 1619-1622.

[72] N. Gogolla, J.J. LeBlanc, K.B. Quast, T.C. Südhof, M. Fagiolini, T.K. Hensch, Common circuit defect of excitatory-inhibitory balance in mouse models of autism, Journal of Neurodevelopmental Disorders 1 (2009) 172-181.

[73] D.H. Ebert, M.E. Greenberg, Activity-dependent neuronal signalling and autism spectrum disorder, Nature 493 (2013) 327-337. 
[74] A.J. Willsey, S.J. Sanders, M. Li, S. Dong, A.T. Tebbenkamp, R.A. Muhle, S.K. Reilly, L. Lin, S. Fertuzinhos, J.A. Miller, M.T. Murtha, C. Bichsel, W. Niu, J. Cotney, A.G. Ercan-Sencicek, J. Gockley, A.R. Gupta, W. Han, X. He, E.J. Hoffman, L. Klei, J. Lei, W. Liu, L. Liu, C. Lu, X. Xu, Y. Zhu, S.M. Mane, E.S. Lein, L. Wei, J.P. Noonan, K. Roeder, B. Devlin, N. Šestan, M.W. State, Coexpression Networks Implicate Human Midfetal Deep Cortical Projection Neurons in the Pathogenesis of Autism, Cell 155 (2013) 997-1007.

[75] N.N. Parikshak, R. Luo, A. Zhang, H. Won, J.K. Lowe, V. Chandran, S. Horvath, D.H. Geschwind, Integrative functional genomic analyses implicate specific molecular pathways and circuits in autism, Cell 155 (2013) 1008-1021.

[76] L.M. Xu, J.R. Li, Y. Huang, M. Zhao, X. Tang, L. Wei, AutismKB: an evidence-based knowledgebase of autism genetics, Nucleic Acids Res 40 (2012) D1016-1022.

[77] C.M. Durand, J. Perroy, F. Loll, D. Perrais, L. Fagni, T. Bourgeron, M. Montcouquiol, N. Sans, SHANK3 mutations identified in autism lead to modification of dendritic spine morphology via an actin-dependent mechanism, Mol Psychiatry 17 (2012) 7184.

[78] Z. Xie, R.L. Huganir, P. Penzes, Activity-dependent dendritic spine structural plasticity is regulated by small GTPase Rap1 and its target AF-6, Neuron 48 (2005) 605-618.

[79] S.J. Tsai, Is autism caused by early hyperactivity of brain-derived neurotrophic factor?, Med Hypotheses 65 (2005) 79-82.

[80] S.C. Nagamani, F. Zhang, O.A. Shchelochkov, W. Bi, Z. Ou, F. Scaglia, F.J. Probst, M. Shinawi, C. Eng, J.V. Hunter, S. Sparagana, E. Lagoe, C.T. Fong, M. Pearson, M. Doco-Fenzy, E. Landais, M. Mozelle, A.C. Chinault, A. Patel, C.A. Bacino, T. Sahoo, S.H. Kang, S.W. Cheung, J.R. Lupski, P. Stankiewicz, Microdeletions including YWHAE in the Miller-Dieker syndrome region on chromosome $17 \mathrm{p} 13.3$ result in facial dysmorphisms, growth restriction, and cognitive impairment, J Med Genet 46 (2009) 825-833.

[81] O. Zuk, E. Hechter, S.R. Sunyaev, E.S. Lander, The mystery of missing heritability: Genetic interactions create phantom heritability, Proc Natl Acad Sci U S A 109 (2012) 1193-1198.

[82] T. Aida, R. Imahashi, K. Tanaka, Translating human genetics into mouse: the impact of ultra-rapid in vivo genome editing, Dev Growth Differ 56 (2014) 34-45. 
1 Figure legend

2

3 Figure 1. Idiogram for most frequent chromosomal abnormalities associated with ASD

4 A total of 26 loci were shown in this ideogram. These loci were represented as red bands.

5 Note that many loci are located in telomere proximal regions.

6

7 Figure 2. Network 1 from Pathway analysis

8 Ingenuity pathway analysis (IPA) was performed to identify the biological networks

9 underlying ASD. Genes or their products were shown as nodes. Lines between each node

10 indicate biological relationships, such as transcriptional suppression or protein-protein

11 interaction. The genes with colors are included in AutismKB core dataset. The gradation of

12 the color is positively correlated with the overall evidence-based score of the gene as ASD

13 related genes summarized in AutismKB. The shape represents the functional categories of the

14 gene. The network 1 contains genes that carry functions in the regulation of behavior, cell-to-

15 cell signaling and interaction, nervous system development.

17 Figure 3. Network 2 from Pathway analysis

18 The genes in network 2 are characterized as related with neurological diseases, psychological 19 disorders, organismal injury and abnormalities. BDNF, MECP2, ERK1/2, and GABA 20 receptors were identified as hubs of this network.

21

22 Figure 4. Network 3 from Pathway analysis

23 The functions of the third network are associated with developmental disorder, hereditary

24 disorder and neurological disease. The central hub in this network is AP-1 transcription 25 factor, which closely connected by HRAS, PTEN, Creb and Mapk and MAPK3. 


\section{Table 1 - Frequ}

Locus

15q11.2-q13.1

$16 p 11.2$

$2 p 16.3$

$1 q 21.1$

$7 q 11.23$

$3 q 29$

$22 q 11.2$

17p11.2

$17 q 12$ 


\section{Figure}

Figure 1

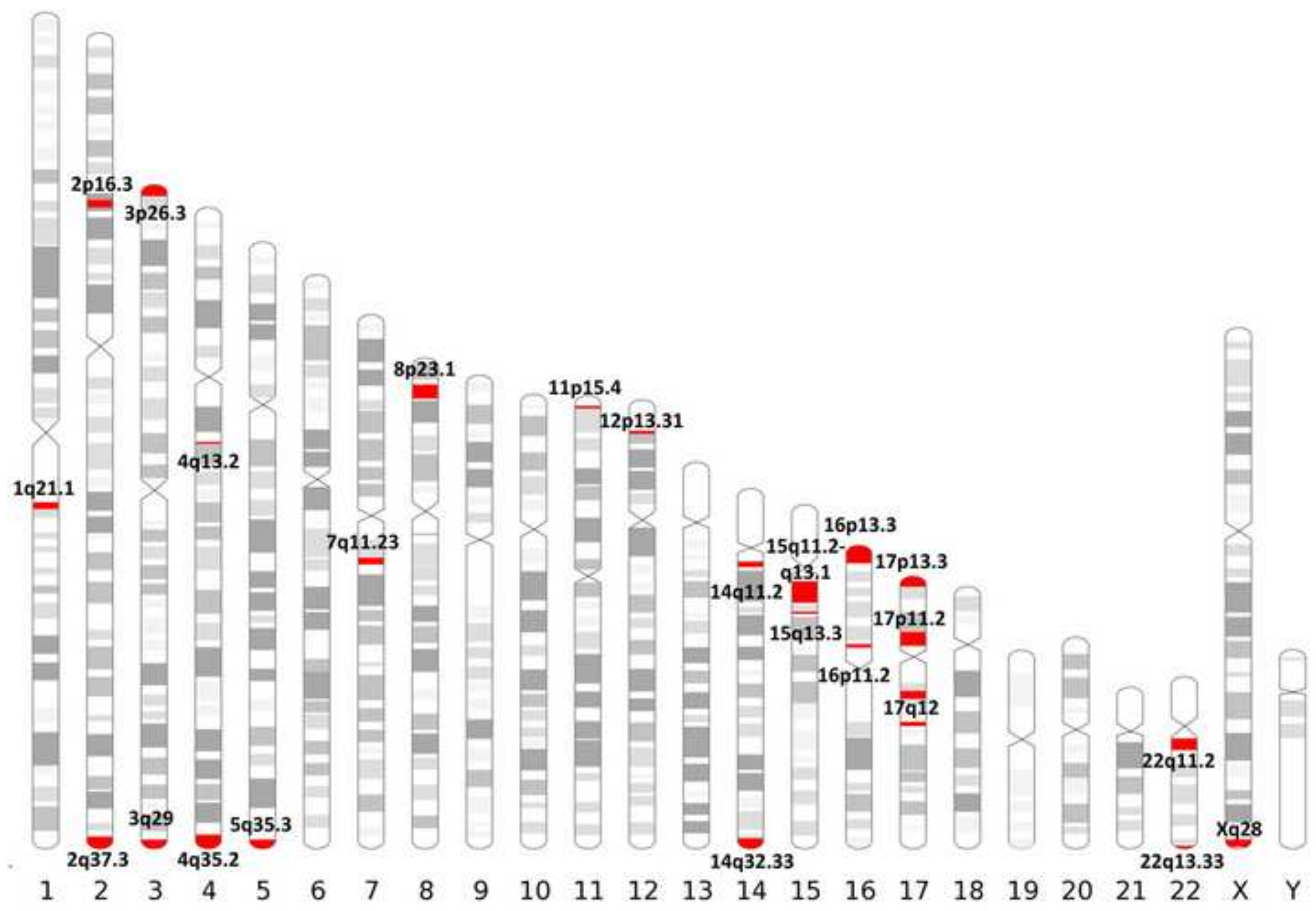



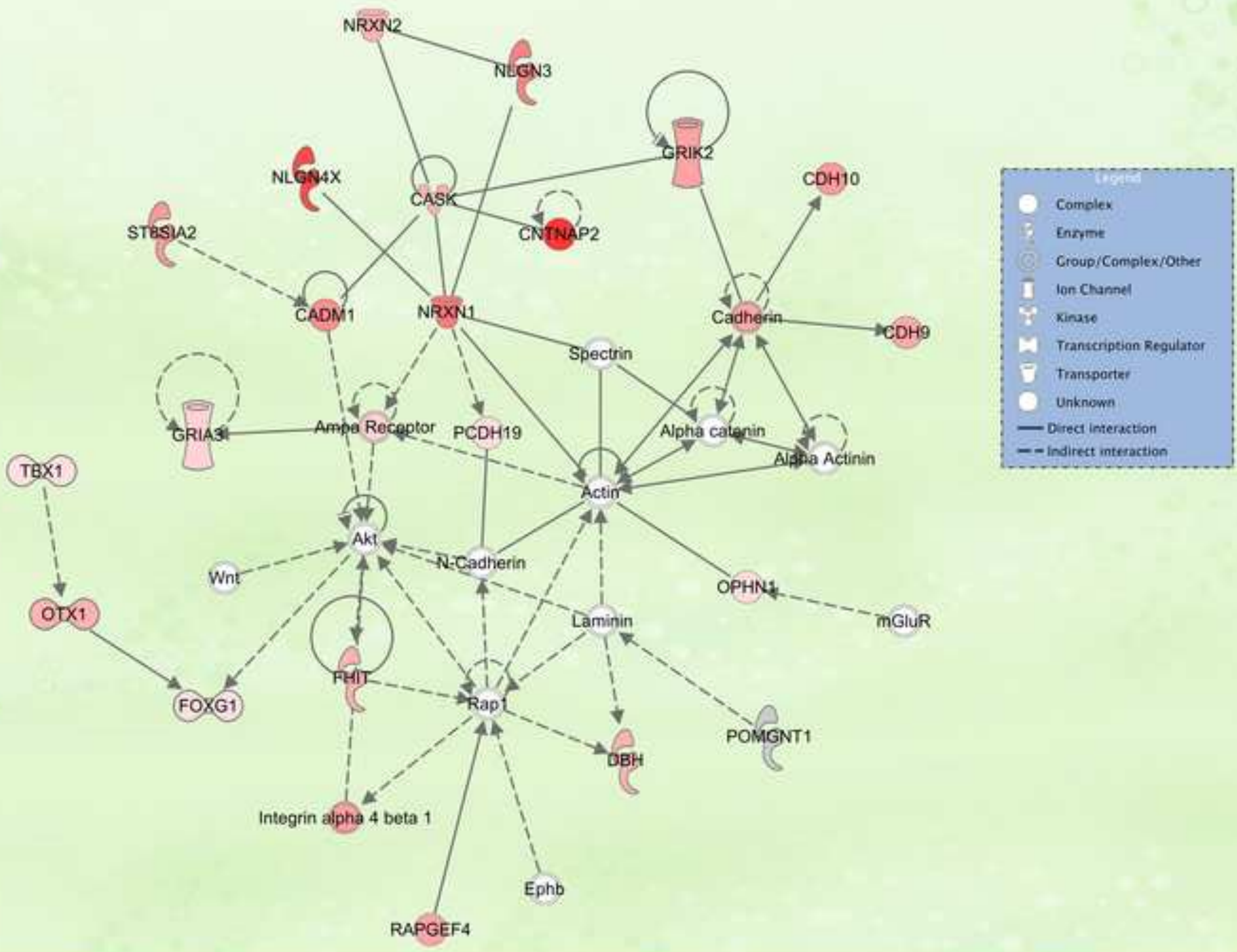


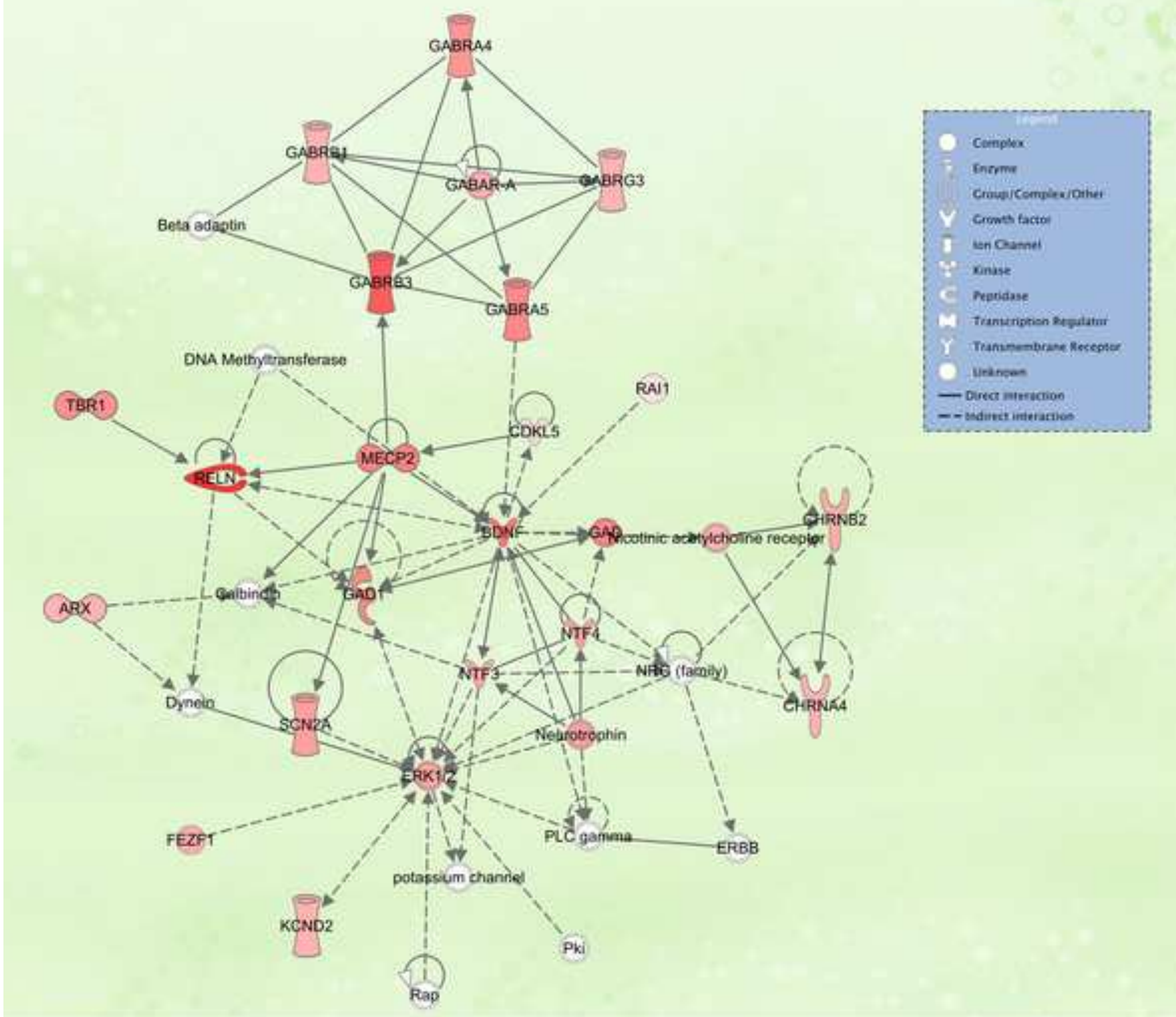

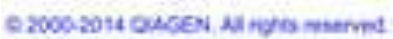




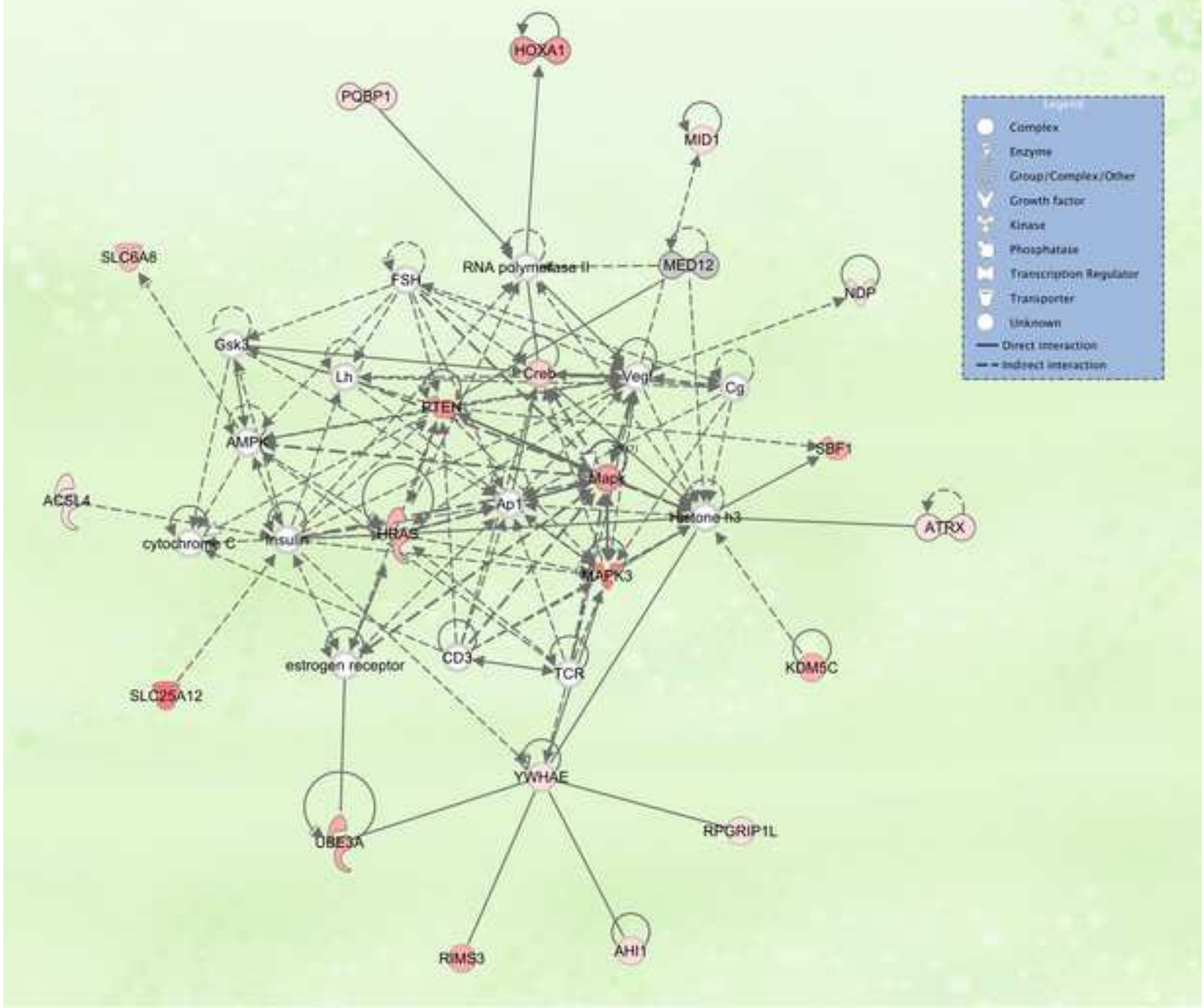

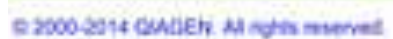

